\title{
Pemilihan, Penyimpanan dan Stabilitas Sampel Toksikologi pada Korban Penyalahgunaan Narkotika
}

\author{
Citra Manela
}

\begin{abstract}
Abstrak
Kasus penyalahgunaan narkotika semakin meningkat. Toksikologi forensik mempelajari tentang ilmu dan aplikasi toksikologi untuk kepentingan hukum. Kerja utama dari toksikologi forensik adalah melakukan analisis kualitatif maupun kuantitatif dari racun. Untuk memperoleh hasil pemeriksaan yang dapat dipertanggung jawabkan, maka syarat-syarat pengambilan, pemilihan, penyimpanan, dan pengiriman sampel toksikologi ke laboratorium harus dipenuhi dan benar-benar diperhatikan. Hal ini penting karena setiap obat memiliki stabilitas yang berbeda-beda sehingga nantinya akan mempengaruhi hasil analisis racun baik pada korban hidup maupun pada jenazah (post mortem).
\end{abstract}

Kata kunci: sampel, penyalahgunaan narkotika

\begin{abstract}
Cases of drug abuse are increasing. Forensic toxicology learn about science and toxicology applications for legal purposes. The main work of forensic toxicology is the qualitative and quantitative analysis of toxins. To obtain the test results that can be reliable, then the terms of the retrieval, selection, storage, and shipment of samples to the toxicology laboratory must be filled and properly addressed. This is important because each drug has a different stability so that will affect the results of the analysis of toxins both in life and on the victim's body (post mortem).
\end{abstract}

Keywords: sample, drug abused

Affiliasi penulis : Bagian Forensik Fakultas Kedokteran Universitas Andalas / RS M Djamil Padang

Korespondensi : Citra Manela, email : manela_84@yahoo.com, telp: 081382363552

\section{Pendahuluan}

Kasus penyalahgunaan narkotika semakin hari semakin meningkat. Diperkirakan antara 153-300 juta jiwa atau sebesar $3,4 \%-6,6 \%$ penyalahguna narkotika di dunia usia 15-64 tahun pernah mengkonsumsi narkotik sekali dalam setahun, dimana hampir 12\% (15,5 juta jiwa sampai dengan 38,6 juta jiwa) dari pengguna adalah pecandu berat. Menurut data terakhir dari Badan Narkotika Nasional (BNN) tahun 2012, jumlah pecandu narkotika yang mendapatkan pelayanan terapi dan rehabilitasi diseluruh Indonesia tahun 2012 menurut data Deputi Bidang Rehabilitasi BNN adalah sebanyak 14.510 orang, dengan jumlah terbanyak pada kelompok usia
26-40 tahun yaitu sebanyak 9.972 orang. Jenis narkoba yang paling banyak digunakan oelh pecandu yang mendapatkan pelayanan terapi dan rehabilitasi adalah shabu (4.697 orang), selanjutnya secara berurutan adalah jenis ganja (4.175 orang), heroin (3. 455 orang), ekstasi (1.536 orang) dan opiat (736 orang). ${ }^{1}$

Narkotika menurut UU no 35 tahun 2009 adalah zat atau obat yang berasal dari tanaman atau bukan tanaman, baik sintetis maupun semisintetis yang dapat menyebabkan penurunan atau perubahan kesadaran, hilangnya rasa, mengurangi sampai menghilangkan rasa nyeri dan dapat menimbulkan ketergantungan yang dibedakan ke dalam golongan-golongan sebagaimana yang terlampir dalam Undang-Undang. Sedangkan penyalah guna adalah orang yang menggunakan narkotika tanpa hak atau melawan hukum. $^{2}$ 
Toksikologi forensik mempelajari tentang ilmu dan aplikasi toksikologi untuk kepentingan hukum. Kerja utama dari toksikologi forensik adalah melakukan analisis kualitatif maupun kuantitatif dari racun sebagai bukti fisik serta melakukan interpretasi hasil analisis racun tersebut baik pada korban hidup maupun pada korban yang telah meninggal. ${ }^{3,4}$

Untuk memperoleh hasil pemeriksaan yang dapat dipertanggung-jawabkan, maka syarat-syarat pengambilan, pemilihan, penyimpanan, dan pengiriman sampel toksikologi ke laboratorium harus dipenuhi dan benar-benar diperhatikan. Hal ini penting karena setiap obat memiliki stabilitas yang berbedabeda sehingga nantinya akan mempengaruhi hasil analisis racun. ${ }^{4}$

Pada saat pemilihan sampel untuk toksikologi untuk korban penyalahguna narkotika beberapa hal harus dipertimbangkan yaitu sampel mudah untuk dianalisis, sampel mudah didapatkan, pertimbangkan juga apakah yang dicari obat induk atau metabolitnya, waktu deteksi obat, stabilitas obat pada spesimen, volume sampel yang diperlukan serta apakah referensi data kuantitatif obat terhadap sampel yang kita pilih tersedia. $^{5}$

Penyimpanan sampel merupakan hal yang penting diperhatikan. Hal ini karena setelah pengambilan sampel, proses degradasi obat oleh enzim tetap berlangsung walaupun diluar tubuh. Degradasi ini diminimalisir dengan penyimpanan sampel dengan pengawet yang adekuat dan disimpan disuhu yang rendah yaitu kulkas suhu $40^{\circ} \mathrm{C}$ untuk waktu yang tidak begitu lama dan $-20^{\circ} \mathrm{C}$ untuk waktu lebih dari 2 minggu. ${ }^{5}$

Untuk mendapatkan hasil yang valid dalam melakukan analisis toksikologi, kita perlu mengenali sifat dan stabilitas dari analit. Studi-studi yang dilakukan oleh Giorgi SN dan Meeker JE terhadap stabilitas kokain, benzoylecgonin, methampetamin, amphetamin, morfin, codein dan phencyclidine selama 5 tahun didapatkan hasil bahwa obat yang paling tidak stabil adalah kokain, benzoylecgonin dan morfin. Sedangkan methampetamine dan PCP bersifat stabil. ${ }^{6}$ Penelitian yang dilakukan oleh Jessica M Jones dkk, tentang stabilitas 6 MAM pada plasma tikus yang ditambahkan natrium florida didapatkan penurunan konsentrasi 6 MAM sebanyak $6,7 \%-8,3 \%$ setelah satu minggu penyimpanan. ${ }^{7}$

\section{Pemilihan sampel}

Pemilihan sampel merupakan tahap yang penting dalam sebuah kasus keracunan. Royal college of pathologist, bagian forensik dan medikolegal telah menerbitkan guidelines untuk menangani spesimen medikolegal dalam hal menjaga rantai barang bukti. ${ }^{8}$

Pada saat pemilihan sampel untuk toksikologi pertimbangkan hal berikut:

1. Sampel mudah untuk dianalisis

2. Sampel mudah didapatkan, tidak invasif

3. Pertimbangkan apakah yang dicari obat induk atau metabolitnya

4. Waktu obat masih terdeteksi pada spesimen

5. Stabilitas obat pada spesimen

6. Volume sampel

7. Referensi data apakah tersedia

Tabel 1. Keuntungan dan kerugian dari spesimen biologis antemortem dan postmortem ${ }^{5}$

\begin{tabular}{llll}
\hline Spesimen & \multicolumn{2}{l}{ Keuntungan } & \multicolumn{2}{l}{ Kerugian } \\
\hline Darah & Untuk penggunaan & Invasif \\
(ante & obat yang baru & - & Pengambilan \\
mortem) & (jam - hari) & sampel harus \\
& Kadar kuantitatif & oleh petugas \\
& obat berhubungan & medis \\
& dengan efek & Waktu deteksi \\
& farmakologis yang & obat pendek \\
& ditimbulkan & \\
& Referensi datanya & \\
Darah & banyak & \\
(post & Lihat diatas & Dipengaruhi \\
mortem) & (AM) & redistribusi \\
& Data rasio obat di & postmortem \\
& sentral dan perifer & Dipengaruhi \\
& telah diketahui & artefak \\
& untuk beberapa & postmortem \\
& obat & Volume darah \\
& & perifer terbatas \\
\hline
\end{tabular}




\begin{tabular}{|c|c|c|c|c|}
\hline Otak & - & $\begin{array}{l}\text { Digunakan untuk } \\
\text { obat yang larut } \\
\text { lemak, mudah } \\
\text { menguap dan obat } \\
\text { yang bekerja di } \\
\text { susunan syaraf } \\
\text { pusat }\end{array}$ & - & $\begin{array}{l}\text { Matriks tidak } \\
\text { homogen } \\
\text { Matriks kompleks } \\
\text { Preparasi sampel } \\
\text { sulit } \\
\text { Referensi data } \\
\text { terbatas }\end{array}$ \\
\hline Empedu & - & $\begin{array}{l}\text { Identifikasi untuk } \\
\text { obat yang baru } \\
\text { ditelan atau obat } \\
\text { yang absorpsinya } \\
\text { lama }\end{array}$ & - & $\begin{array}{l}\text { Matriks tidak } \\
\text { homogen } \\
\text { Matriks kompleks } \\
\text { Memerlukan } \\
\text { preparasi sampel }\end{array}$ \\
\hline Rambut & - & $\begin{array}{l}\text { Untuk pemakaian } \\
\text { obat yang sudah } \\
\text { lama (bulan) } \\
\text { Tersedia, mudah } \\
\text { diperoleh } \\
\text { Berguna untuk obat } \\
\text { dan analit bukan } \\
\text { obat seperti logam }\end{array}$ & - & $\begin{array}{l}\text { Membutuhkan } \\
\text { teknologi yang } \\
\text { baru dalam } \\
\text { analisisnya } \\
\text { Pemakaian obat } \\
\text { baru tidak bisa } \\
\text { dideteksi } \\
\text { Kontaminasi } \\
\text { lingkungan } \\
\text { Bias etnik } \\
\text { Referensi data } \\
\text { kurang }\end{array}$ \\
\hline Urine & - & $\begin{array}{l}\text { Mudah didapatkan } \\
\text { Waktu deteksi lebih } \\
\text { lama dibandingkan } \\
\text { darah }\end{array}$ & - & $\begin{array}{l}\text { Potensial } \\
\text { dimanipulasi } \\
\text { Obat induk jarang } \\
\text { ditemukan, hanya } \\
\text { dalam bentuk } \\
\text { metabolitnya } \\
\text { Kadar kuantitatif } \\
\text { tidak } \\
\text { berhubungan } \\
\text { dengan efek } \\
\text { farmakologinya }\end{array}$ \\
\hline
\end{tabular}

Tabel 2. Jumlah sampel yang diambil ${ }^{5}$

\begin{tabular}{llll}
\hline Postmortem & \multicolumn{3}{c}{ Antemortem } \\
\hline Spesimen & Jumlah & Spesimen & Jumlah \\
Darah & $25 \mathrm{ml}$ & Darah & $10-20 \mathrm{ml}$ \\
Urine & Semua & Urine & $25-100 \mathrm{ml}$ \\
Rambut & $150-200$ & Rambut & Sejumput, \\
& helai atau & & sebesar \\
& $50 \mathrm{mg}$ & & pena \\
Otak & $50 \mathrm{gr}$ & \\
Empedu & $50 \mathrm{gr}$ & & \\
& $(150-200$ & & \\
& rambut $)$ & & \\
& & & \\
\hline
\end{tabular}

\section{Penyimpanan sampel}

Penyimpanan sampel merupakan suatu tahap yang memegang peranan penting dalam kasus keracunan, terutama pada kasus dimana sampel tidak bisa langsung dilakukan analisis dilaboratorium. ${ }^{5}$ Contohnya karena jauhnya jarak ke laboratorium rujukan serta laboratorium rujukan yang tidak membuka pelayanan setiap hari selama 24 jam.

\section{Darah}

Untuk kasus-kasus dimana sampel untuk pemeriksaan kuantitatif obat tidak bisa dilakukan pemeriksaan langsung ke laboratorium maka sampel darah harus disimpan pada temperatur yang sesuai dan bahan pengawet yang adekuat. Pada penyimpanan yang tidak begitu lama maka penyimpanan yang direkomendasikan adalah pada kulkas suhu $4^{\circ} \mathrm{C}$, jika butuh waktu yang lama (lebih dari 2 minggu) maka disimpan pada freezer suhu $20^{\circ} \mathrm{C}$. Kematian bakteri akan terjadi sangat cepat pada suhu $-20^{\circ} \mathrm{C}$ dan terjadi lambat pada suhu $4^{\circ} \mathrm{C}$. Pada suhu yang rendah enzim juga inaktif.

Pengawet dan antikoagulan biasanya ditambahkan pada sampel darah terutama untuk pemeriksaan yang membutuhkan waktu yang lama ke fasilitas laboratorium. Pengawet yang dipakai adalah Natrium Florida 2\%. Tabung komersial yang sering tersedia (bertutup abu-abu) berisi natrium florida sebagai pengawet dan potasium oksalat sebagai antikoagulan. Natrium florida ini dapat menghambat perkembangan bakteri dan kerja enzim, sehingga sangat diperlukan dalam penyimpanan sampel yang diduga mengandung etanol, cocaine, heroin dan lainlain. Flouride bekerja sebagai penghambat kerja enzim dan menghambat terjadinya glikolisis. ${ }^{5}$

Natrium florida pertama kali dikenal sebagai antikoagulan darah. Kemudian dalam perkembangannya natrium florida dikenal dengan sebagai zat yang dapat menjaga kadar glukosa darah. Sehingga ditambahkan pada darah untuk pemeriksaan kadar glukosa jika sampel darah tidak langsung dilakukan pemeriksaan dilaboratorium. Penelitian yang dilakukan oleh A.Y.W Chan, R. Swaminathan dan C.S Cockram membandingkan antara natrium florida dan 
heparin didapatkan bahwa natrium florida efektif menjaga kadar gula darah hingga hari ketiga. ${ }^{9}$

Penelitian yang dilakukan oleh Raymond Gambino et al didapatkan hasil bahwa penurunan kadar glukosa pada 4 jam pertama bisa dikurangi dengan penambahan bufer citrat. Pada sampel darah yang ditambahkan natrium florida, EDTA dan bufer citrat terjadi penurunan kadar glukosa $0,3 \%$ pada jam kedua dan 1,2\% pada 24 jam pertama. Pada sampel darah yang hanya ditambahkan Natrium florida dan EDTA terjadi penurunan kadar glukosa $4,6 \%$ pada 2 jam pertama dan penurunan $7 \%$ pada 24 jam pertama. $^{10}$

Pada perkembangannya natrium florida juga digunakan untuk sampel toksikologi. Kontaminasi bakteri dapat mengubah glukosa menjadi etanol melalui proses glikolisis dan menyebabkan hasil negatif palsu. Untuk sampel yang mengandung alkohol karena penyimpanan sampel sebelum pemeriksaan, kadar alkohol dapat meningkat. Untuk mengatasi hal ini maka pada sampel darah yang mengandung alkohol harus ditambahkan natrium florida untuk menghambat aktifitas enzim dan mikroorganisme yang dapat menghasilkan ethanol dalam sampel darah. Pengawet yang dianjurkan adalah natrium florida $1 \%$ yang mempunyai efek antiglikolisis. $^{11}$

Selain penggunaan untuk sampel darah yang mengandung alkohol, natrium florida juga ditambahkan pada sampel darah yang mengandung narkotika terutama narkotika yang sifatnya tidak stabil yaitu heroin, morfin dan kokain. ${ }^{10}$ Konsentrasi natrium florida yang direkomendasikan untuk pemeriksaan toksikologi adalah 1 - 4\%. Sedangkan jika lebih dari $4 \%$ maka akan terjadi hemolisis. ${ }^{11}$ Natrium florida merupakan antikoagulan yang lemah sehingga sering dikombinasikan dengan potasium oksalat yang bekerja sebagai antikoagulan. Potasium oksalat bekerja dengan cara mengikat kalsium sehingga tidak terjadi pembekuan darah tidak terjadi. ${ }^{12,13}$

Selain menghambat enzim, natrium florida juga bersifat menghambat pertumbuhan mikroorganisme yang berperan dalam proses degradasi obat diluar tubuh. Hal ini karena natrium florida bekerja sebagai antiglikolisis didalam tubuh bakteri sehingga bakteri tidak dapat menggunakan gula yang ada di sampel darah sebagai sumber makanan. ${ }^{14}$

Mikroorganisme sendiri juga menghasilkan enzim yang menambah terjadinya degradasi obat. Mikroorganisme tersebut juga menggunakan gugus karbon dari morfin sebagai sumber energinya. Penelitian yang dilakukan oleh Bruce Neil dan kawankawan tentang degradasi oleh mikroba terhadap alkaloid morfin didapatkan bahwa bakteri yang ada didarah (Pseudomonas putida M 10) menggunakan karbon dari morfin untuk sumber energi. Degradasi morfin diperantarai oleh $N A D P^{+}$dan morphine dehydrogenase menjadi NADPH dan morphinone. Morphine dehydrogenase ini dihasilkan Pseudomonas putida M $10 .^{15}$

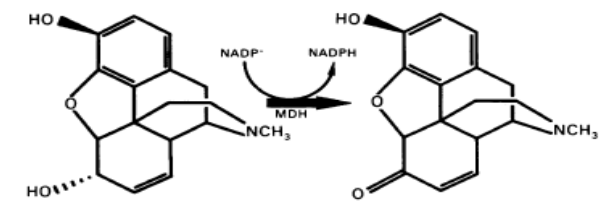

Morfin Morphinone

Gambar 1. Oksidasi morfin menjadi morphinone yang dikatalisis oleh morphine dehydrogenase dari P.putida M10. $^{15}$

Penelitian yang dilakukan oleh Liras Paloma dkk tentang transformasi enzimatik morfin oleh enzim hydroxysteroid dehydrogenase yang dihasilkan oleh Pseudomonas testosteroni terlihat bahwa hydroxysteroid dehydrogenase mendegradasi morfin menjadi 14-hydroxy morphinone. ${ }^{16}$

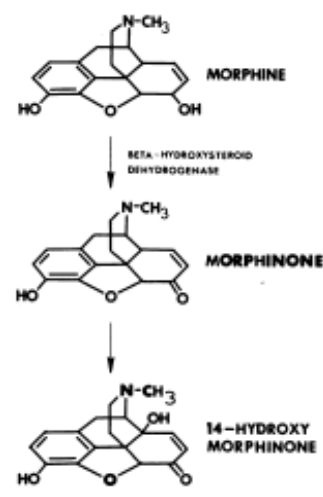

Gambar 2. Transformasi morfin oleh hydroxysteroid dehydrogenase. ${ }^{17}$ 
Tabung komersial yang biasa tersedia dengan bermacam-macam pengawet dan antikoagulan (EDTA, citrate, heparin, clot activator, dan lain-lain) walaupun dibuat untuk keperluan klinis yang berneda tetapi tidak cocok digunakan untuk tujuan penyimpanan sampel toksikologi obat. Antikoagulan yang terbaik untuk sampel toksikologi forensik adalah potasium oksalatdi banding EDTA, heparin dan sitrat. Antioksidan seperti asam askorbat $(0,25 \% \mathrm{w} / \mathrm{v})$ atau sodium metabisulfite $(1 \% \mathrm{w} / \mathrm{v})$ juga ditambahkan untuk menghambat kehilangan oksidatif. Untuk obat yang dipengaruhi oleh $\mathrm{PH}$ (acid labile dan alkali labile) seperti kokain, 6 acetylmorphine, maka ditambahkan larutan buffer. Untuk spesimen yang sangat dipengaruhi oleh cahaya (photo labile) maka disimpan ditabung dan dicegah agar tidak kena cahaya dengan menutup tabung dengan foil. ${ }^{5}$

Pengawetan secara fisik adalah suhu yang rendah. Pada suhu yang rendah mikroorganisme dan enzim akan inaktif. Hidrolisis morfin menjadi morphine 3 glucoronide dan morphine 6 glucoronide meningkat dengan peningkatan suhu dan lama penyimpanan. Penyimpanan sampel darah postmortem pada suhu $20^{\circ} \mathrm{C}$ mencegah terjadinya hidrolisis glucoronide. Pada penyimpanan di freezer (suhu $-20^{\circ} \mathrm{C}$ ) akan membunuh bakteri dengan cepat. Sedangkan penyimpanan dikulkas (suhu $4^{\circ} \mathrm{C}$ ) akan membunuh bakteri tetapi lebih lambat. Oleh sebab itu penyimpanan untuk waktu yang lebih lama (lebih dari 2 minggu) penyimpanan di freezer direkomendasikan. Enzim juga akan inaktif pada suhu $4^{0} \mathrm{C}$ tetapi sifatnya reversibel. Sehingga jika terjadi kenaikan suhu maka enzim akan aktif kembali. ${ }^{5}$

Dari beberapa studi yang telah dilakukan menunjukkan bahwa konsentrasi obat di darah dapat mengalami perubahan terutama jika disimpan di suhu ruangan. Penelitian yang dilakukan oleh Vermeire tentang stabilitas morfin pada suhu ruangan terlihat adanya degradasi morfin menjadi pseudomorfin dan morphine $\mathrm{N}$ oxide. ${ }^{18}$

Semua sampel harus diberi identitas berupa nama, no kasus (rekam medis), tanggal dan waktu pengambilan sampel, tanda tangan serta inisial nama yang mengambil sampel tersebut. Kontaminasi spesimen juga perlu dipikirkan, baik dari kontainer maupun faktor dari luar. Penyimpanan sampel pada tabung plastik juga harus dipertimbangkan karena dibutylphthalate dapat mempengaruhi analisis obat dengan gas chromatographic mass spectrometric. ${ }^{5}$

$\underline{\text { Urine }}$

Untuk kasus korban hidup, urine diambil yaitu urine pancar tengah, disimpan di botol plastik steril dengan pengawet natrium florida. Sampel urine berisfat lebih stabil dibanding darah. Penyimpanan disuhu ruangan masih memungkinkan, tetapi lebih baik jika disimpan dikulkas suhu $4^{0} \mathrm{C} .{ }^{5}$

\section{$\underline{\text { Rambut }}$}

Untuk sampel rambut cukup disimpan di suhu ruangan dalam keadaan bersih dan kering. ${ }^{5}$

\section{Stabilitas sampel}

Untuk mendapatkan hasil yang valid dalam melakukan analisis toksikologi, kita perlu mengenali sifat dan stabilitas dari analit. Secara umum stabilitas obat pada sampel toksikologi dipengaruhi oleh degradasi metabolik dan perubahan kimia atau gabungan dari kedua hal tersebut. ${ }^{5}$ Studi-studi yang dilakukan oleh Giorgi SN dan Meeker JE terhadap stabilitas kokain, benzoylecgonin, methampetamin, amphetamin, morfin, codein dan phencyclidine selama 5 tahun didapatkan hasil bahwa obat yang paling tidak stabil adalah kokain, benzoylecgonin dan morfin. Sedangkan methampetamine dan PCP bersifat stabil. ${ }^{6}$ Penelitian yang dilakukan oleh Jessica M Jones et al, tentang stabilitas 6 MAM pada plasma tikus yang ditambahkan natrium florida didapatkan penurunan konsentrasi 6 MAM sebanyak $6,7 \%-8,3 \%$ setelah satu minggu penyimpanan. ${ }^{7}$

Berikut dijelaskan tentang stabilitas beberapa jenis narkotika :

1. Amphetamine

Methampetamin dan amphetamin pada sampel urin diberikan pengawet natrium florida $1 \%$ dan disimpan di kulkas suhu $-20^{\circ} \mathrm{C}$ dapat bertahan hingga 1 tahun. Sebuah studi tentang penyimpanan darah yang mengandung metahampetamine pada 
suhu ruangan selama 5 tahun didapatkan penurunan signifikan methampetamine yaitu $9 \%$ pada bulan ke tiga dan penurunan kadar $38 \%$ pada 5 tahun penyimpanan. Hasil ini menunjukkan bahwa amphetamin sedikit lebih stabil dibandingkan methampetamine. Sampel di simpan di tabung yang mengandung natrium florida dan potasium oksalat sebanyak $10 \mathrm{ml}$. Walaupun metahmpetamine dan amphetamine ini termasuk golongan yang stabil, penyimpnanan sampel di suhu ruangan tidak dianjurkan untuk mencegah kerusakan obat.

Penelitian lain tentang stabilitas golongan amphetamin pada urine, darah dan air selama 21 minggu pada suhu $-20^{\circ} \mathrm{C}, 4^{\circ} \mathrm{C}$ dan $20^{\circ} \mathrm{C}$ didapatkan hasil bahwa semua obat stabil pada suhu $-20^{\circ} \mathrm{C}$ sedangkan pada sampel darah yang disimpan di suhu $20^{\circ} \mathrm{C}$ dan $4^{\circ} \mathrm{C}$ terjadi degradasi matrix pada minggu ke 5 dan minggu ke $13 .^{5}$

\section{Ganja}

THC (ganja) akan mengalami penguraian jika terkena udara, panas dan cahaya. Ganja akan mengalami hidrolisis menjadi cannabidiol atau dioksidasi menjadi cannabinol sebagai hasil kontak dengan udara atau kondisi asam. THC dilaporkan stabil dikulkas selama 6 bulan dan disuhu ruangan selama 2 minggu. Ikatan THC dengan zat yang larut air seperti bahan kontainer dan tutup tabung dari karet harus diperhatikan. Contohnya sampel darah yang mengandung THC disimpan ditabung kaca stabil selama 4 hari disuhu ruangan dan 4 minggu di suhu $20^{\circ} \mathrm{C}$. Sampel yang sama disimpan pada tabung berbahan polystyrene menunjukkan penurunan konsentrasi $60-100 \%$. Prinsipnya metabolit obat lebih stabil dari obat induknya. Pada sebuah studi, sampel urine yang mengandung 11 nor 9 carboxi tetrahydrocannabinol (THCA) stabil difreezer hingga 1 tahun. Urine diberi pengawet natrium florida 1\%. Studi ini menggunakan tabung kaca untuk penyimpanan sampel urine. ${ }^{5}$

\section{Opioids}

6 Monoacetylmorphine merupakan metabolit yang labil dari diamorphine. 6 MAM akan mengalami deasetilasi selama penyimpanan diamorphine (heroin). Heroin dalam tubuh akan dihidrolisis menjadi 6 monoacetylmorphine dan morfin oleh enzim pseudocholinesterase dan carboxylesterase form 1 dan form 2 (HCE -1 dan HCE- 2). ${ }^{10,11,20} 6$ Monoacetylmorphine merupakan metabolit diamorphine yang labil karena hidrolisis dari ikatan ester. 6 Monoacetylmorphine mengalami deasetilasi menjadi morfin selama penyimpanan. Degradasi morfin dikatalisis oleh esterase yang ada di darah. Setelah darah diambil dari dalam tubuh, maka proses degradasi pada sampel darah oleh enzim tetap berjalan. Oleh sebab itu untuk menghambat degradasi obat oleh mikroorganisme dan enzim ini dilakukan pengawetan baik secara fisik maupun kimia. ${ }^{5}$

Pengawetan darah secara kimia yaitu salah satunya dengan penambahan natrium florida. Natrium florida merupakan esterase inhibitor. ${ }^{5}$ Natrium florida merupakan enzim inhibitor yang nonkompetitif dimana inhibitor berikatan dengan enzim pada sisi yang bukan sisi aktif. Ikatan enzim dan inhibitor ini akan merubah bentuk sisi aktif dari enzim sehingga enzim tidak akan berikatan dengan substrat. $^{19}$

Karena heroin cepat mengalami degradasi baik in vivo maupun in vitro maka selain penambahan natrium florida dan disimpan di suhu yang rendah maka perlu juga dipertimbangkan penambahan buffer (10 mM formate) karena stabilitas heroin terjadi pada $\mathrm{pH} 3$, begitu juga dengan penambahan antikoagulan. ${ }^{11}$

4. Phencyclidine

PCP merupakan obat yang relatif stabil dari beberapa penelitian. Penyimpanan PCP pada suhu ruangan akan stabil hingga 18 bulan. Walaupun begitu penurunan signifikan konsentrasi PCP pernah dilaporkan pada sampel darah yang telah diberikan pengawet yang disimpan disuhu ruangan selama 5 tahun. ${ }^{5}$ PCP pada sampel darah yang ditambahkan natrium florida akan stabil selama 3 tahun sedangkan jika tidak ditambahkan natrium florida akan stabil selama 1 tahun. $^{20}$

\section{Kokain}

Kokakin mempunyai stabilitas yang sangat buruk karena transformasi kimia dan enzimatik yang menghasilkan produk hidrolisis. Konversi spontan kokain menjadi benzoylecgonine terjadi karena kenaikan $\mathrm{pH}$. Pada $\mathrm{pH} 5$ tidak terjadi penurunan 
konsentrasi kokain setelah 21 hari dibandingkan pada $\mathrm{pH} 8$ terjadi penurunan konsentrasi $40-70 \%{ }^{5}$

\section{Aspek hukum Pidana}

Pada dasarnya narkotika hanya digunakan untuk pelayanan kesehatan dan/ atau pengembangan ilmu pengetahuan, kecuali golongan I yang tidak digunakan untuk pelayanan kesehatan. Seseorang hanya dapat menggunakan, menyimpan, memiliki apabila menerima narkotika dari tenaga medis dalam kaitannya dengan upaya pengobatan penyakitnya. Dokter, apotik dan sarana kesehatan diwajibkan untuk melakukan pencatatan dan pelaporan atas kegiatannya yang berkaitan dengan narkotika, pemakai narkotika harus membuktikan bahwa perolehannya dan pemakaiannya adalah sah dan pecandu narkotika wajib menjalani pengobatan dan perawatan.

Pelanggaran atas ketentuan undang-undang diancam dengan sanksi pidana sebagaimana yang diatur dalam UU no.35 tahun 2009 tentang narkotika. Sanksi-sanksi tersebut diancamkan kepada "setiap orang yang tanpa hak atau melawan hukum menanam, memelihara, memiliki, menyimpan, menguasai, atau menyediakan Narkotika Golongan I dalam bentuk tanaman, dipidana dengan pidana penjara paling singkat 4 tahun dan paling lama 12 tahun dan pidana denda paling sedikit Rp. 800 . 000.000 dan paling banyak Rp.8.000.000.000".

Masuknya seseorang ke dalam jeratan ketergantungan akan mengakibatkan kebutuhan zat narkoba secara pasti meningkat dan terus menerus. Keadaan ini tentu saja berdampak kepada meningkatnya kebutuhan finansialnya dalam upaya memperoleh zat tersebut. Bagi mereka yang memiliki sumber daya keuangan cukup maka ia akan dapat bertahan lama, tetapi mereka yang terbatas sumber daya ekonominya, maka ia akan mulai menjual barang-barangnya sendiri kemudian mencuri uang atau barang orang lain atau terjebak ke dalam protitusi atau kegiatan kejahatan terorganisasi lainnya. ${ }^{21}$

\section{Daftar Pustaka}

1. Butar-butar Darwin. Jurnal data pencegahan dan pemberantasan penyalahgunaan dan peredaran gelap narkoba tahun 2012. Edisi tahun 2013. Badan Narkotika Nasional Republik Indonesia. 2013.

2. UU no. 35 tahun 2009 tentang narkotika

3. DiMaio VJ, DiMaio D. Interpretive Toxicology: Drug Abuse and Drug Deaths. In: Forensic Pathology,. $2^{\text {rd }}$ ed. Florida: CRC Press; 2001. p.521-58

4. Wirasuta Made Agus. Analisis Toksikologi Forensik dan Interpretasi Temuan Analisis. Indonesian Journal of Legal and Forensic Science. 2008; 1(1): 47-55

5. S Kerrigan. Sampling, storage and Stability. In : Clarke's Analytical Forensic Toxicology. $2^{\text {rd }}$ ed.2008;p.335-54

6. Giorgi SN, Meeker JE. A 5 year stability study of common illicit drugs in blood. Journal Analysis Toxicology.1995; 19(6): 392-398.

7. Jessica M Jones, Michael D. Raleigh, Paul R. Pentel, Theresa M. Harmon, Daniel E. Keyler, Rory P. Remmel, et al. Stability of heroin, 6 monoacetylmorphine, and morphine in biological samples and validation of an LC-MS assay for delayed analyses of pharmacokinetic samples in rats. Journal of Pharceutical and biomedical analysis.2013: 74: 291-7.

8. Recommendations for collection of forensic specimens from complainants and suspects.Faculty of Forensic and Legal Medicine. 2011

9. Chan A Y W, Swaminathan R, Cockram C S. Effectiveness of natrium floride as presevatives of glucose in blood. Clinical Chemistry. 1989; 35(2): 315-7.

10. Raymond Gambino, Janet Piscitelli, Tomy A. Ackattupathil, Judy L. Theriault, Reynaldo 
D. Andrin, Michael L. Sanfilippo, et al. Acidification of blood is superior to sodium floride alone as an inhibitor of glycolysis. Clinical Chemistry. 2009;55(5):1019-1021

11. Kaye S. The Collection and handling of the blood alcohol specimen. American Journal of Clinical Pathology. November 1980;74 (5).

12. Cornelis Jan, Burkens Johan. The use of sodium floride as a blood anticoagulant in blood phosphorus determination. From Laboratory of General Pathology, University of Amsterdam. 1935 : 796-798.

13. Mitsou Narita, Masayuki Hino, Takayuki Takubo, Noriyuki Tatsumi. Analogues EDTA and Sodium Flouride as anticoagulants.Osaka City Medical Journal. 2000; 46(1):71-87

14. Saukko Pekka, Knight Bernard. Poisoning and Pathologist. In : Knight's Forensic Pathology. $3^{\text {rd }}$ ed. Edward Arnold. UK. 2004. p. 541-551

15. Liras paloma, Kasparian Stephen S, Umbreit Wayne W. Enzymatic transformation of morphine by hydroxysteroid dehydrogenase from Pseodomonas testosteroni. American
Society for Microbiology. October 1975; 30 (4): 650-656

16. Vermeire A, Remon J P. Stability and compability of morphine. International Journal of Pharmaceutics.1999; 87: 17-51.

17. M.Espinosa Bosch, A.Ruiz Sanchez, F.Sanchez Rojas, C. Bosch Ojeda. Morphine and its metabolites : analytical methodologies for its determination. Journal of Pharmaceutical and biomedical analysis.2007; $43: 799-815$

18. Karch Steven B. Karch's Pathology of Drug Abused. Third Edition. CRC Press. 2002.

19. Marks Dawn B, Marks Allan B, Smith Colleen M. Biokimia Kedokteran Dasar. EGC. Jakarta. 2000.

20. Grieshaber Alison, Costantino Anthony, Lappas Nicolas. Stabilityof Phencyclidine in stored blood sample. Journal of Analytical Toxicology. 1998 ; 22 : 515-519.

21. Sampurna Budi, Samsu Zulhasmar, Siswaja Dwija Tjetjep. Penyalahgunaan narkoba dalam : Peranan IImu Forensik dalam Penegakan Hukum. Jakarta. 2008. p.299306 